\title{
Patterns in national policies for support of low achievers in reading across Europe
}

\author{
Akvile Motiejunaite $^{\mathrm{a} \star}$, Sogol Noorani ${ }^{\mathrm{a}}$ and \\ Christian Monseur ${ }^{\mathrm{b}}$ \\ ${ }^{\mathrm{a}}$ Eurydice, EACEA (Europe Commission), Belgium; ${ }^{\mathrm{b}}$ Department of Education and \\ Training, Faculty of Psychology and Education, University of Liège, Belgium
}

This paper brings together data on national policies for improving reading achievement with student reading outcomes according to the OECD Programme for International Student Assessment (PISA) 2009 data. It is based on a two-step analysis. Firstly, the prevalence of national policies for improving reading achievement (i.e., specialist reading teachers, national tests for identifying individual learning needs and curriculum guidelines on reading comprehension strategies) is described in 32 European countries. Secondly, a three-level regression analysis is performed in order to assess the relative impact of the analysed national policies. The results indicate that the provision of reading specialists for providing targeted support to students with difficulties and advice to teachers seems to be the most important measure. Moreover, central level regulation by education authorities can be an effective way to assure the right to a reading specialist for every student in need.

\section{Introduction: what do we know about the causes of low achievement in reading?}

The successful acquisition of reading skills during childhood and adolescence is fundamental for young people to allow them to pursue their personal goals when embarking on adult life. Moreover, good literacy skills are the basis of a child's entire school career; without them academic success is unattainable. For these reasons, causes for reading difficulties have been extensively researched. The main sources for drawing valid conclusions from cross-country comparisons have been the international student achievement surveys PISA (Programme for International Student Assessment) and PIRLS (Progress in International Reading Literacy Study). PISA and - to a lesser extent-PIRLS have triggered diverse reactions and reform measures in education systems around the globe.

There is a wide consensus that socio-economic background and home environment have a very significant impact on school achievement, including in reading (see, e.g., Breen \& Jonsson, 2005; Mullis et al., 2007; OECD, 2004, 2010b). The majority of students with reading difficulties are boys who come from socio-economically disadvantaged families and who tend to lack educational resources, including books. Yet the extent of the influence of home and family background varies across countries. The strength of the relationship could be seen an indicator of overall equality of the education system (Dobbins \& Martens, 2012).

\footnotetext{
${ }^{\star}$ Corresponding author. Education Audiovisual and Culture Executive Agency, Avenue du Bourget 1, BOU2, 01/100, BE-1140 Brussels, Belgium. Email: Akvile.Motiejunaite@ec.europa.eu
} 
School level factors have also been extensively researched using contextual questionnaires of international student achievement surveys. School autonomy in textbook choice and hiring teachers has been shown to have positive effects on student achievement (Fuchs \& Woessmann, 2007; Woessmann et al., 2007). However, school autonomy may be conducive to student achievement in well-developed systems but detrimental in low-performing systems (Hanushek et al., 2012). Research also indicates that school disciplinary problems are associated with lower student performance (Arum \& Velez, 2012; Fini, 2007).

There is, however, less information and less agreement regarding the impact of national policies and characteristics of education systems on reading achievement. As countries of similar prosperity produce very different educational results (OECD, 2010a), the success of an education system seems to depend more on how educational resources are invested than on the volume of investment (OECD, 2012a). A few known results regarding the impact of characteristics of education systems include a positive influence of the amount of time spent in pre-primary education (Mullis et al., 2007) and the negative impact of grade repetition (OECD, 2012b). Also, in countries and schools where students are guided into different tracks based on their abilities, overall performance is not improved, but socio-economic differences are accentuated (Hanushek \& Woessmann, 2006; Marks et al., 2006; OECD, 2004, 2010c; Van de Werfhorst \& Mijs, 2010). Most of the analyses of country-level characteristics are based on derivative indicators from contextual questionnaires; studies linking data from other sources to international survey results are rarer.

There remains a lack of evidence on the effectiveness of educational policies for tackling low achievement. This paper aims to address this gap by bringing together data on certain national policies ${ }^{1}$ for tackling reading difficulties with the actual student outcomes according to the latest PISA 2009 data. However, it is important to note that country-level variables have much less explanatory potential than individual-level or school-level variables. Indeed, differences between 32 analysed European countries explain only $7 \%$ of the total variance of reading performance, while between-school differences represent $38 \%$ and within school $55 \%$ of total variance. ${ }^{2}$ In case of educational policies, it might be related to different levels of implementation due to regional variations and school autonomy.

Despite the limitations in explanatory power, this paper is based on the assumption that it is possible to identify certain strategies or approaches at country level that help to tackle the problem of low achievement in reading. In order to reach this aim, some of the main national policies for support to low achievers are described and the countries are classified according to the prevailing patterns. This part of the analysis is based on comparative data from the Eurydice Network on Education Systems and Policies in Europe E $^{3}$ on national policies for improving reading achievement. The analysed national measures include the provision of specialist reading teachers in classrooms, the administration of national tests for identifying individual learning needs and the existence of curriculum guidelines on reading comprehension strategies.

Subsequently, an attempt is made to identify if certain patterns of support are more effective than others. The outcomes of the educational systems are analysed using reading achievement results from PISA 2009. ${ }^{4}$ The analysis covers 32 
European education systems that are members of Eurydice Network and participated in PISA 2009.

The paper is structured as follows. First, a review of current research literature provides the theoretical background for the analysed national approaches for tackling low achievement in reading. This is followed by a section explaining the methodology and in particular the Eurydice data used. Finally, the results are presented and discussed, along with specific reflection on the added value and limitations of this kind of macro-level analysis.

\section{National policies for improving reading achievement}

The present analysis examines three aspects of national policy aiming to improve reading achievement, namely the availability of specialist reading teachers, national tests for identifying individual learning needs and curriculum guidelines on reading comprehension strategies. These support measures cover crucial areas in the different phases of reading literacy. Reading specialist support and national tests are mostly used during the primary level of education, or the 'learning to read' phase. Timely detection of reading difficulties through national tests identifying individual learning needs and targeted help of reading specialists is essential. Reading comprehension strategies, on the other hand, are important not only in the primary education, but also in the later years, or in the 'reading to learn' phase. Inclusion of curriculum guidelines on reading comprehension strategies in our analysis therefore aims to highlight that attention to reading in school should not end with the 'learning to read' phase, but continue in secondary levels of education promoting high levels of understanding and reflection on written texts. Moreover, Eurydice data has shown that there is considerable variation in European countries in the national policies for these support measures.

Table 1 includes a short description of all the analysed approaches for tackling low achievement in reading.

\section{Reading specialists}

Even with excellent instruction, some students fail to make satisfactory progress in reading. They might thus require and benefit from additional support from a reading

Table 1. Short description of the analysed approaches for tackling low achievement in reading

\begin{tabular}{|c|c|}
\hline $\begin{array}{l}\text { Reading } \\
\text { specialist }\end{array}$ & $\begin{array}{l}\text { Provides individual or small group intensive instruction that is coordinated } \\
\text { with the classroom instruction given by the teacher. Reading specialists are } \\
\text { fully-qualified teachers that have additional, specific qualifications in } \\
\text { teaching reading and dealing with reading difficulties. }\end{array}$ \\
\hline $\begin{array}{l}\text { National tests } \\
\text { identifying } \\
\text { individual } \\
\text { learning needs }\end{array}$ & $\begin{array}{l}\text { Tests, used for early detection of reading difficulties by helping to identify } \\
\text { the specific learning needs of individual students and to define appropriate } \\
\text { personalised follow-up and teaching. }\end{array}$ \\
\hline $\begin{array}{l}\text { Reading } \\
\text { comprehension } \\
\text { strategies }\end{array}$ & $\begin{array}{l}\text { Specific procedures that enable students to become aware of how well they } \\
\text { comprehend the text as they read, and improve their understanding and } \\
\text { learning from it. }\end{array}$ \\
\hline
\end{tabular}


specialist who can provide individual or small-group intensive instruction in close coordination with the classroom instruction given by the teacher. Reading specialists are fully-qualified teachers with additional, specific qualifications, exceeding those of normal classroom teachers. Based on their advanced knowledge, competences and skills, reading specialists can help to adapt or modify reading instruction for students with reading difficulties, either directly or indirectly, through supporting the professional learning of the teachers and thus add to high-quality reading instruction in schools.

Research evidence highlights the importance of specialised reading professionals for teaching children to read (Allington, 2006; Bean et al., 2003; Darling-Hammond, 2006; Mokhtari et al., 2009; Taylor et al., 2000). These and similar studies also highlight the crucial role of reading specialists in preventing and tackling reading difficulties in young children (e.g., Bean, 2009; Snow et al., 1998; IRA, 2010). Their support can be particularly effective if it is available directly in the classroom or in the students' school. The conclusions of a study carried out by the US National Research Council (Snow, 1998) on preventing reading difficulties in young children highlight the importance of ensuring that well-trained reading specialists are available for direct interventions with children and for on-going support to classroom teachers.

In addition to improving classroom instruction, reading specialists also have an important role in the context of student assessment and providing adequate feedback about the learning needs of students back to classroom teachers and parents. Moreover, reading specialists can act as a resource person to communicate students' developments in reading to other specialised staff, e.g., educational psychologists, speech therapists or special educators (IRA, 2000).

\section{National tests identifying individual learning needs}

While appropriate instruction can effectively enhance the development of students' reading skills, proper and continuous assessment is an equally vital part of the process of teaching and learning. In particular formative assessment can play an important role in supporting students' reading skills development through an in-depth evaluation of their reading ability and progress (Black \& Wiliam, 1998; Garbe et al., 2009; OECD, 2005). National tests-also referred to as standardised assessment-can likewise benefit teaching and learning if the results data offers the capacity for teachers to diagnose students' progress (Griffin et al., 2010). National tests are often used to ensure that the performances of individual students are readily comparable. They provide students with information about their own acquired knowledge which can be compared to that of their peers and the national averages. Teachers also use the results of some national tests to compare the learning attainment of individual students, identify specific learning needs and adapt their teaching accordingly.

Research evidence confirms the positive impact of national tests that identify individual learning needs on students' literacy learning outcomes (e.g., Halverson et al., 2005; Mokhtari et al., 2007). Moreover, studies in several countries (Demailly, 2001; Helgøy \& Homme, 2007; House of Commons, 2007; Johnson \& Duffett, 2003) have shown the favourable acceptance of such national tests by many teachers, thus preparing a positive basis for their use. Teacher involvement and positive attitudes are 
especially important in the educational systems where teachers and schools enjoy high levels of autonomy.

National tests can provide a good indication of students' reading comprehension provided that it is done in parallel with discussions and feedback that inform instruction and support students' individual learning needs.

\section{Reading comprehension strategies}

National curricula ${ }^{5}$ for teaching reading establish the basic frameworks within which teachers are required or advised to develop their own teaching to meet their students' needs. Although there may be differences in the extent to which individual teachers adhere to national recommendations, research suggests that national frameworks and curricula have a strong impact on actual teaching practice (Crahay et al., 2006).

Among the most effective teaching practices for promoting reading literacy and helping struggling readers are teaching reading comprehension strategies, continuity of phonics instruction and text-based collaborative learning (EACEA \& Eurydice, 2011). Continuity of phonics instruction and text-based collaborative learning were widely recommended in many education systems and seem not to distinguish countries regarding the proportions of low achievers in reading. Therefore only the recommendations to use reading comprehension strategies are analysed in this paper.

Reading comprehension strategies are specific procedures that enable students to become aware of how well they are comprehending the text as they read, and improve their understanding and learning from it. As struggling readers tend to have a very small repertoire of reading comprehension strategies and may often choose to read on further in a text even if they do not understand it, teaching students to use reading comprehension strategies can help them to better understand a text before, during and after reading.

There has been much support in recent years for the explicit teaching of reading comprehension strategies throughout schooling. The idea behind this approach, as stated by the National Reading Panel (NICHD, 2000), is that reading comprehension can be improved by teaching students to use specific cognitive strategies or to reason strategically when they encounter barriers to comprehension as they read. In addition, the National Reading Panel noted that a number of these strategies are more effective when used as part of a multiple-strategy method. The combined use of several strategies can lead to more effective learning, better transfer of learning, increased memory and general improvements in comprehension.

Recent research in Europe provides evidence for the benefits of teaching reading comprehension strategies in primary and secondary levels of education (Brooks, 2007; Takala, 2006; Spörer et al., 2009). A comparative study of good practices in European Countries for teaching struggling adolescent readers (Garbe et al., 2009) confirms the lack of command over reading comprehension strategies to be among the main obstacles in these students' reading skills.

Following this reasoning, in this paper we expect that lower levels of low achievers in reading are to be found in those education systems where national policies for improving reading achievement exist. These measures include, in decreasing order of importance: 
- Reading specialists.

- National tests identifying individual learning needs.

- Reading comprehension strategies.

\section{Methodology}

This research paper is based on a two-step analysis. Firstly, data from the Eurydice Network on Education Systems and Policies in Europe is used to describe European countries according to their national policies targeting low achievers (i.e., specialist reading teachers, national tests for identifying individual learning needs and curriculum guidelines on reading comprehension strategies). Secondly, the educational outcomes in these European countries are explored analysing reading achievement of 15-year-old students according to the PISA 2009 data. ${ }^{6}$ It consists of 197,146 students, 7428 schools and 32 countries.

Such hierarchical data (students within schools within countries) violate the independence assumption of classical models such as the least square error linear regression. Multilevel modelling is an appropriate alternative as it has been designed to handle such dependencies in the data (Raudenbush, 1988; Snijders \& Bosker, 1999).

In this research, a three-level regression analysis was performed with HLM 6.06 (Raudenbush et al., 2004) with students at level one, schools at level two and country at level three.

No independent variables were regressed at levels 1 and 2 and the three above mentioned variables describing national policies targeting low achievers were introduced in the model at the country level. The variable labelled PV1READ in the PISA 2009 database was used as dependant variables and the student final weight W_FSTUWT was standardized as recommended in the PISA 2006 Data Base Manual (OECD, 2009). Data were therefore weighted at level 1 in HLM and fixed and random parameters were estimated according to the full maximum likelihood method. The level 3 independent variables are introduced in the model uncenterered.

The multilevel regression equations can be written as follows:

$$
\begin{aligned}
& Y_{i j k}=\beta_{0 j k}+\varepsilon_{i j k} \\
& \beta_{0 j k}=\beta_{00 k}+U_{0 j k} \\
& \beta_{00 k}=\gamma_{000}+\gamma_{001}(\text { Specialits })+\gamma_{002}(\text { guidelines })+\gamma_{003}(\text { strategies })+U_{00 k}
\end{aligned}
$$

The following sub-sections describe in detail the operationalisation of the variables used for describing the national policies targeting low achievers in reading.

\section{Variable 1: Reading specialists}

According to national regulations of nine European education systems-Ireland, Poland, the United Kingdom, and in all five Nordic countries (Denmark, Finland, Iceland, Sweden and Norway), primary school teachers can request the help of a specialist reading teacher to assist them in the classroom (European Commission/ EACEA/Eurydice, 2012) (see Table 2). Two types of specialist teachers can be 
Table 2. Approaches for tackling low achievement in reading

\begin{tabular}{|c|c|c|c|}
\hline Education systems & $\begin{array}{l}\text { Reading } \\
\text { specialist }\end{array}$ & $\begin{array}{l}\text { National test } \\
\text { (identifying } \\
\text { individual needs) }\end{array}$ & $\begin{array}{l}\text { Reading } \\
\text { comprehension } \\
\text { strategies }^{\star}\end{array}$ \\
\hline Denmark & Yes & Yes & ISCED 1-2 \\
\hline Ireland & Yes & Yes & ISCED 1 \\
\hline Finland & Yes & No & ISCED 1 \\
\hline Sweden & Yes & Yes & No \\
\hline England/Wales/Northern Ireland & Yes & Yes & ISCED 1 \\
\hline Scotland & Yes & Yes & No \\
\hline Iceland & Yes & Yes & No \\
\hline Norway & Yes & Yes & ISCED 1 \\
\hline Poland & Yes & No & No \\
\hline Belgium (French) & No & Yes & ISCED 1-2 \\
\hline Belgium (German) & No & No & ISCED 1 \\
\hline Spain & No & No & ISCED 1-2 \\
\hline France & No & Yes & No \\
\hline Luxembourg & No & Yes & ISCED 1 \\
\hline Hungary & No & Yes & No \\
\hline Netherlands & No & No & ISCED 1 \\
\hline Slovenia & No & No & ISCED 1-2 \\
\hline Liechtenstein & No & No & ISCED 1-2 \\
\hline Turkey & No & No & ISCED 1 \\
\hline Belgium (Flemish) & No & No & No \\
\hline Bulgaria & No & No & No \\
\hline Czech Republic & No & No & No \\
\hline Germany & No & No & No \\
\hline Estonia & No & No & No \\
\hline Greece & No & No & No \\
\hline Italy & No & No & No \\
\hline Latvia & No & No & No \\
\hline Lithuania & No & No & No \\
\hline Austria & No & No & No \\
\hline Portugal & No & No & No \\
\hline Romania & No & No & No \\
\hline Slovakia & No & No & No \\
\hline
\end{tabular}

Notes: ${ }^{\star}$ Five or six different reading comprehension strategies are recommended in primary level curricula (ISCED 1) or in curricula for primary and lower secondary level (ISCE 1-2).

distinguished, those who have had specific training to provide support to students with reading difficulties, and those who are qualified as educational staff dealing with special needs and who, in addition, are specialised in teaching reading and helping students with reading difficulties.

In Denmark, the Laesevejleder provides support and guidance on methods and materials for tackling reading difficulties to teachers, parents and students. In Norway, classroom teachers can contact reading literacy teachers who are specialised in learning support and teaching reading and writing. In Ireland as well as in the United Kingdom (England, Wales and Northern Ireland) some teachers have been trained as Reading Recovery ${ }^{7}$ teachers. These teachers are specially trained to provide selected 
children with daily half-hour one-to-one lessons tailored to their needs (EACEA \& Eurydice, 2011).

In Finland, Sweden and Iceland the teachers who support primary schools in tackling students' reading difficulties are those qualified as special needs educational staff who are also specialised in reading. In Finland, the educational staff dealing with special needs receive training on reading difficulties as part of a compulsory programme. They assist classroom teachers in various tasks: diagnosing students' reading skills; providing learning support in the form of individualised tasks and use of time; giving guidance and counselling; and developing flexible arrangements, such as flexible grouping, simultaneous teaching, etc. In Sweden, the Speciallärare are teachers in special needs education who are trained in, amongst other things, in-depth knowledge of reading techniques and effective methods for encouraging and supporting students' skills in reading at an early stage. One part of the special needs service in Iceland, which is supported by the municipalities, includes appropriate support for students who have difficulties with reading and for teachers who need assistance in helping students with reading difficulties (EACEA \& Eurydice, 2011).

\section{Variable 2: National tests identifying individual learning needs}

In the context of this analysis, only national tests that can be used to support the learning processes by clarifying the specific learning needs of individual students and identifying appropriate personalised follow-up and teaching have been considered. Although far less is at stake for individual students than in tests for the award of certificates, these standardised tests - in conjunction with continuous assessment by teachers-are important in improving performance and can lead to significant learning gains.

The EACEA/Eurydice (2009a) data shows that 10 of the European education systems considered here organise national tests identifying individual learning needs, namely Belgium (French Community), Denmark, France, Luxembourg, Hungary, Sweden, the United Kingdom (England and Scotland), Iceland and Norway (see Table 2).

In this type of national tests, several countries rotate the subjects tested, thereby covering more subjects without significantly increasing the burden imposed by testing on students and teachers. However, the subjects most often tested are the language of instruction (reading) and mathematics.

The precise timing of tests differs from one country to the next. Some of the ten national education systems named above organise national tests identifying individual learning needs only before grade four or during the 'learning to read' phase (Hungary and Norway), while in all of the countries concerned national tests are foreseen both before and after grade four, thus covering both 'learning to read' and 'reading to learn' phases.

\section{Variable 3: Reading comprehension strategies}

For defining the countries that provide curriculum guidelines for reading comprehension strategies, the paper uses the EACEA/Eurydice (2011) analysis of national 
curricula for primary and secondary levels of education related to the language of instruction. One of the key elements of the analysis were teaching approaches linked to reading comprehension strategies.

In order to assess how much emphasis is placed on the teaching of reading comprehension strategies in national curricula, the following range of processes (or strategies) used to enhance students' comprehension were considered:

- Drawing inferences or interpretations while reading text and graphic data.

- Summarising text and focusing selectively on the most important information.

- Making connections between different parts of a text.

- Using background knowledge.

- Checking/monitoring own comprehension.

- Constructing visual representations.

All European countries assign specific objectives for reading comprehension at primary and lower secondary education and the vast majority of curricula include specific parts or sections where reading comprehension strategies are mentioned. However, the teaching of reading comprehension is more effective when it combines the use of several strategies. The present analysis is therefore taking into consideration only those education systems that recommend a wide range of different strategies (five or six) to enhance students' reading comprehension. As shown in Table 2, primary level curricula in 13 education systems make such recommendations. Curricula for lower secondary level offering such a broad range of strategies exist only in Belgium (French Community), Denmark, Spain, Slovenia and Liechtenstein. Generally, in a majority of countries where national curricula for primary level mention at least three of the six key reading comprehension strategies selected for this analysis, the range is reduced in lower secondary level.

Based on data on the prevalence of national policies on reading specialists, formative national tests and curriculum guidelines regarding reading comprehension strategies, three different patterns of support for struggling readers can be observed in European countries (see Table 2):

(1) Education systems with extensive national policies for tackling low achievement in reading. In these education systems reading specialists are available for providing support to students with reading difficulties and national tests that help to detect learning difficulties are administered. In many of these education systems the use of various reading comprehension strategies is recommended in the national curriculum. These education systems tend to tackle the problem of low achievement at an early stage (primary level of education). Moreover, teachers can easily approach professionals that have a specialisation in reading difficulties for advice or refer students for intensive individual- or group-work. Scandinavian countries (Denmark, Finland, Sweden, Iceland and Norway), as well as Ireland, Poland and the United Kingdom have highly developed national support structures for struggling readers. The central regulations in these countries provide for reading specialist support in mainstream schooling, and most of these countries have national tests identifying individual needs and/or recommend extensive use of comprehension strategies. 
(2) Education systems with some national policies for tackling low achievement. These countries administer national tests identifying individual learning needs or have central level recommendations for using a wide range of reading comprehension strategies (or both), but do not stipulate, at central level, the right for reading specialist support. Ten education systems (Belgium [French and German-speaking communities], Spain, France, Luxembourg, Hungary, the Netherlands, Slovenia, Liechtenstein and Turkey) belong to this group.

(3) Education systems with limited/no national policies for tackling low achievement. They provide no support of reading specialists and no screening for reading difficulties via national testing. The use of various reading comprehension strategies is also not encouraged in national curricula. Thirteen education systems do not provide at central level any of the analysed measures of support for students with difficulties in reading. Most Eastern European countries belong to this group. ${ }^{8}$

\section{Results and discussion}

A three-level regression modelling was used for analysing the PISA 2009 student achievement in reading data. The first step in analysing data via multilevel modelling is to calculate a fully unconditional model or the simplest model that contains no predictor variables at any level. It is used to understand the basic structure of the data and to obtain the estimates of the amount of variance explained at each level in the model. Comparison of these estimates with the final model determines the amount of variance explained by the added independent variables (Raudenbush \& Bryk, 2002). The variance estimates for the unconditional model (model without any independent variables) are respectively equal to 666, 3691 and 5239 for levels 1, 2 and 3. In other words, differences between European countries explain $7 \%$ of the total variance of reading performance, while between-school differences represent $38 \%$ and within school 55\% of total variance. Therefore, in the European countries, students' educational chances are only modestly affected by the country in which they live.

Table 3 shows the random effect estimates or the variance components of the final model with three independent variables at country level. The level 3 variance difference between unconditional and final model indicates the amount of variance explained when adding the three variables at country level. As level 3 variance reported in the final model equals 436 , the three independent variables explain $35.5 \%$ of the level 3 variance. ${ }^{9}$

Table 4 shows the estimation of the fixed effects of the analysed education policies on average student achievement. The results demonstrate that the provision of

Table 3. Random effect estimates of the three level regression analysis

\begin{tabular}{lllll}
\hline Random effect & Variance & DF & $\chi^{2}$ & P-value \\
\hline Level 3 & 436 & 28 & 642.9 & 0.000 \\
Level 2 & 3692 & 7396 & 139420.2 & 0.000 \\
Level 1 & 5239 & & & \\
\hline
\end{tabular}


Table 4. Fixed effect estimates of the three level regression analysis

\begin{tabular}{lcccr}
\hline Fixed effect & Coefficient & Standard error & t Ratio & P-value \\
\hline Intercept (G000) & 468.82 & 6.51 & 72.00 & 0.000 \\
Specialists (G001) & 35.27 & 7.19 & 4.90 & 0.000 \\
Formative tests (G002) & -3.47 & 7.90 & -0.44 & 0.664 \\
Strategies (G003) & 2.58 & 6.30 & 0.41 & 0.685 \\
\hline
\end{tabular}

Note: The estimates reflect the metric of the overall reading scale, which is based on a mean for OECD countries set at 500 in PISA 2000 (with a standard deviation of 100).

reading specialist is associated significantly with the country's performance in reading. On average, availability of reading specialists is associated with an increase of the mean achievement of an education system by 35 points $\left(\gamma_{001}=35.27 ; P<0.001\right)$, which represents about the expected growth due to one year of schooling at that age (see OECD, 2010a).

Contrary, the other analysed national policies, namely organising national formative tests for identifying individual learning needs or providing curriculum guidelines on how to develop reading strategies, seem to have no impact on the country's mean achievement. Indeed, as p-values for both fixed effects are higher than 0.05 , the nullhypotheses that the effect equals zero, cannot be rejected. In other words, these national policies are not associated with higher country average performance in reading.

These findings must be seen in the context of school autonomy. School autonomy is considered in most countries today as instrument to achieve educational goals: more freedom is given to schools and teachers in order to improve the quality of education. However, there are large differences across Europe in the nature and extent of autonomy (EACEA \& Eurydice, 2007, 2008; OECD, 2011). Concerning reading specialists, EACEA and Eurydice (2011) and PIRLS 2006 data (Mullis et al., 2007, p. 193) shows that in countries with national policies for this form of support measure, the reading specialists are also available in practice. In education systems where central authorities guarantee a right to every school to have a reading specialist, this right is applied widely.

However, the implementation of reading comprehension strategies is less guaranteed even if they are recommended in the curriculum. In Europe, most schools and teachers have a very large degree of autonomy with respect to teaching methods (EACEA \& Eurydice, 2009b). This also has an impact on the effectiveness of national tests identifying individual learning needs: even though they represent an important diagnostic instrument, it is subsequently up to schools and teachers to decide over adequate teaching approaches to tackle students' reading difficulties. Moreover, identification of students with reading difficulties has to be combined with support for teachers regarding how to tackle the problems. Mainstream generalist teachers might not have enough knowledge and skills to support specific reading difficulties even if they are identified.

On the other hand, school autonomy can result in the implementation of good practices even in the absence of national policies. For example, even though central 
level policies in Belgium (Flemish community), Spain, the Netherlands and Slovenia do not provide a right to specialist reading teachers, PIRLS 2006 data shows that in practice a reading specialist is at least sometimes available for over $75 \%$ of fourth grade students (see Mullis et al., 2007, p. 193). The wide availability of reading specialist support can partly explain the low levels of low achievers in reading in Belgium (Flemish community) and the Netherlands.

\section{Conclusions: crucial role of reading specialists}

This paper presented an attempt to link national educational policies with student achievement results as measured by international surveys. Despite the limitations in explanatory power on the education system level, international student achievement surveys proved to be a valuable source of information. Even though only $7 \%$ of variation in student achievement can be explained by country level variables, national policies concerning the provision of reading specialists successfully distinguished these education systems where 15-year-old students achieve better reading results.

The results show that there is a group of European countries (Scandinavian countries, Ireland, Poland and the United Kingdom) with extensive national policies offering targeted support, the most important of which is the provision of reading specialists. Such an approach seems to be associated with the best student outcomes.

The analysis indicates reading specialists may have a crucial role in helping students with reading difficulties to improve. Moreover, central level regulation by education authorities can be an effective way to assure the right to a reading specialist for every student in need.

National tests can help detecting individual students' weaknesses in reading; however, they do not provide any guidance to teachers regarding effective support measures. The reality of large classrooms may further prevent teachers from providing intensive support to individual students. Moreover, national tests are often just a onetime event or at best repeated every school year, which might be too infrequent for a timely detection of learning difficulties. Effective teachers and reading specialists should therefore not wait for these national measures in order to provide support for students facing reading difficulties and apply continuous assessment methods.

Curriculum guidelines on reading comprehension strategies, on the other hand, are important for promoting students' reading literacy and can help improving reading difficulties, even in later years of secondary schooling. However, having such regulations at national level might nevertheless translate into different levels of implementation in different countries, and even for different schools or teachers.

In order to be effective, national strategies for tackling low achievement in reading could therefore build on a solid policy basis and, most importantly, a uniform and practical implementation of the analysed support measures in schools - above all the provision of reading specialists who can work with struggling readers in class as early as reading difficulties appear. Central level regulations guaranteeing reading specialist support for every student can be a good start, which can be implemented by creating master programmes for primary teachers with specialisation in reading or qualification upgrades via continuous professional development. Thus, low achievement could effectively be tackled by providing appropriate targeted support. 


\section{NOTES}

${ }^{1}$ National policies are defined as different kinds of official documents containing guidelines, obligations and/or recommendations for education institutions. Regulations are laws, rules or other order prescribed by public authority to regulate conduct. Recommendations are official documents proposing the use of specific tools, methods and/or strategies for teaching and learning. It does not have mandatory application.

2 As calculated by the unconditional three level regression model, see result section further.

${ }^{3} \mathrm{http}: / /$ eacea.ec.europa.eu/education/eurydice/index_en.php.

${ }^{4}$ As PISA tests reading abilities of 15-year-olds, the impact of orthographic depth and syllabic complexity of languages, which is very important during the first years of reading acquisition (Blomert, 2009; Seymour et al., 2003), becomes less pronounced.

${ }^{5}$ National curricula in this paper is understood as various official documents containing regulations, recommendations and/or guidelines for education policy. They can refer to curriculum content, learning outcomes, assessment arrangements, learning materials and others. Several types of steering documents with different degrees of flexibility in their application can exist at the same time and at the same education level.

${ }^{6}$ In order to ensure the comparability of the results across countries, PISA covers students who are aged between 15 years 3 months and 16 years 2 months at the time of the assessment, and who have completed at least six years of formal schooling, regardless of the type of institution in which they are enrolled, whether they are in full time or part time education, whether they attend academic or vocational programs, and whether they attend public or private schools or foreign schools within the country (OECD, 2010a). Therefore, the number of completed school years and amount of time that students have received formal reading instruction may differ, especially in those countries where grade retention is practiced. For more information on the test and sample design, methodologies used to analyse the data, technical features of the project and quality control mechanisms of PISA 2009, see OECD (2012c).

7 Reading Recovery teachers are specially trained to provide selected children with daily half-hour one-to-one lessons tailored to their needs. The aim is also for schools to capitalise on the professional development provided to Reading Recovery teachers, to advise, mentor and support others in the school with responsibilities for children's literacy, including class teachers, teaching assistants and parents through lighter touch interventions (http://readingrecovery.ioe.ac.uk/).

${ }^{8}$ Education systems with different orthographic depths or the degree of spelling-to-sound consistency are spread among the three groups. For example, Finnish, Finnish, Turkish, Bulgarian, Czech, Polish, Romanian are languages with rather straightforward relationship between letters and sounds, but have different approaches to support reading instruction and varying proportions of low achievers in reading.

9 The percentage of variance explained at level three correspond to the level 3 variance for the unconditional model, (i.e., 666), minus the level 3 residual variance for the model with the 3 independent variables (i.e., 436), the difference being then divided by the unconditional level 3 variance (i.e., 666).

\section{References}

Allington, R.L. (2006) Reading specialists, reading teachers, reading coaches: A question of credentials, Reading Today, 23(4), 16-17.

Arum, R., Velez, M. (Eds) (2012) Improving learning environments: School discipline and student achievement in comparative perspective (Palo Alto, Stanford University Press).

Bean, R.M. (2009) The reading specialist: Leadership in classroom, school, and community (New York, Guilford Press).

Bean, R.M., Swan, A.L. \& Knaub, R. (2003) Reading specialists in schools with exemplary reading programs: Functional, versatile, and prepared, The Reading Teacher, 56(5), 446-455.

Black, P. \& Wiliam, D. (1998) Assessment and classroom learning, Assessment in Education: Principles, Policy and Practice, 5(1), 7-74.

Blomert, L. (2009) Cognitive and educational profiling of reading and reading support within the EU. Final Report PROREAD project nr. 2006-2798, EU-SOCRATES Action 6.1.2 and 6.2.

Breen, R. \& Jonsson, J.O. (2005) Inequality of opportunity in comparative perspective: Recent research on educational attainment and social mobility, Annual Review of Sociology, 31, 223243.

Brooks, G. (2007) What works for pupils with literacy difficulties? The effectiveness of intervention schemes (London, DCSF).

Crahay, M., Audigier, F. \& Dolz, J. (2006) En quoi les curriculums peuvent-ils être objet d'investigation scientifique?, in: F. Audigier, M. Crahay \& J. Dolz (Eds) Curriculum, enseignement et pilotage (De Boeck, Bruxelles). 
Darling-Hammond, L. (2006) No Child Left Behind and high school reform, Harvard Educational Review, 76(4), 642-667.

Demailly, L. (2001) Enjeux de l'évaluation et régulation des systèmes scolaires, in: L. Demailly (Ed) Evaluer les politiques éducatives (Bruxelles, Editions De Boeck Université).

Dobbins, M. \& Martens, K. (2012) Towards an education approach à la finlandaise?, French education policy after PISA, Fournal of Education Policy, 27(1), 23-43.

EACEA \& Eurydice (2007) School autonomy in Europe: Policies and measures (Eurydice, Brussels).

EACEA \& Eurydice (2008) Levels of autonomy and responsibilities of teachers in Europe (Eurydice, Brussels).

EACEA \& Eurydice (2009a) National testing of pupils in Europe: Objectives, organisation and use of results (Eurydice, Brussels).

EACEA \& Eurydice (2009b) Key data on education in Europe (Eurydice, Brussels).

EACEA \& Eurydice (2011) Teaching reading in Europe: Contexts, policies and practices (Eurydice, Brussels).

European Commission, EACEA \& Eurydice (2012) Developing key competences at school in Europe: Challenges and opportunities for policy-2011/12. Eurydice report (Luxembourg, Publications Office of the European Union).

Fini, R. (2007) School achievement in Italy, in: R. Teese, et al. (Eds) International studies in educational inequality, theory and policy (Dordrecht, Springer).

Fuchs, T. \& Woessmann, L. (2007) What accounts for international differences in student performance?, A re-examination using PISA data, Empirical Economics, 32 (2), 433-464.

Garbe, C., Holle, K. \& Weinhold, S. (2009) ADORE project: Teaching adolescent struggling readers. $A$ comparative study of good practices in European countries. Scientific report (Lueneburg, Germany, University of Lueneburg).

Griffin, P., Murray, L., Care, E., Thomas, A. \& Perri, P. (2010) Developmental assessment: Lifting literacy through professional learning teams, Assessment in Education: Principles, Policy and Practice, 17(4), 383-397.

Halverson, R., Grigg, J., Prichett, R. \& Thomas, C. (2005) The new instructional leadership: Creating data-driven instructional systems in schools. WCER Working Paper No. 2005-9 (Madison, WI: University of Wisconsin-Madison, Wisconsin Center for Education Research). Available online at: http://www.wcer.wisc.edu/publications/workingPapers/Working_Paper_No_2005_9. pdf (accessed 30 March 2012).

Hanushek, E.A. \& Woessmann, L. (2006) Does educational tracking affect performance and inequality?, Differences-in-differences evidence across countries, Economic fournal, Royal Economic Society, 116(510), 63-76.

Hanushek, E. A., Link, S. \& Woessmann, L. (2012) Does school autonomy make sense everywhere? Panel estimates from PISA, Journal of Development Economics. Available online at: http:// www.sciencedirect.com/science/article/pii/S0304387812000661 (accessed 8 November 2012).

Helgøy, I. \& Homme, A. (2007) Towards a new professionalism in school?, A comparative study of teacher autonomy in Norway and Sweden, European Educational Research fournal, 6(3), 232-249.

House of Commons (2007) Testing and assessment. Third report of session 2007-08, Children, Schools and Families Committee, London.

International Reading Association (IRA) (2000) Teaching all children to read: The roles of the reading specialist. A position statement of the International Reading Association. Available online at: http://www.reading.org/Libraries/Position_Statements_and_Resolutions/ps1040_specialist. sflb.ashx (accessed 30 March 2012).

IRA (2010) Standards 2010: Reading specialist/literacy coach. Available online at: http://www.reading. org/General/CurrentResearch/Standards/ProfessionalStandards2010/ProfessionalStandards2010_Role5.aspx (accessed 29 March 2012).

Johnson, J. \& Duffett, A. (2003) Where we are now. 12 things you need to know about public opinion and public schools (New York, NY, Public Agenda).

Marks, G.N., Cresswell, J. \& Ainley, J. (2006) Explaining socioeconomic inequalities in student achievement: The role of home and school factors, Educational Research and Evaluation, 12(2), $105-128$. 
Mokhtari, K., Rosemary, C.A. \& Edwards, P.A. (2007) Making instructional decisions based on data: What, how, and why, The Reading Teacher, 61(4), 354-359.

Mokhtari, K., Thoma, J. \& Edwards, P. (2009) How one elementary school uses data to help raise students' reading achievement, The Reading Teacher, 63(4), 334-337.

Mullis, I.V.S., et al. (2007) PIRLS 2006 international report: IEA's progress in international reading literacy study in primary schools in 40 Countries (MA, TIMSS and PIRLS International Study Center, Chestnut Hill).

National Institute of Child Health and Human Development (NICHD) (2000) Teaching children to read: An evidence-based assessment of the scientific research literature on reading and its implications for reading instruction. Report of the National Reading Panel (Washington, DC, US Government Printing Office).

Organisation for Economic Co-operation and Development (OECD) (2004) Messages from PISA 2000 (Paris, OECD).

OECD (2005) Formative assessment -Improving learning in secondary classrooms (Paris, OECD).

OECD (2009) PISA data analysis manual: SPSS and SAS, 2nd edn (Paris, OECD).

OECD (2010a) PISA 2009 results: What students know and can do (Volume I) (Paris, OECD).

OECD (2010b) PISA 2009 results: Overcoming social background-Equity in learning opportunities and outcomes (Volume II) (Paris, OECD).

OECD (2010c) PISA 2009 results: What makes a school successful? Resources, policies and practices (Volume IV) (Paris, OECD).

OECD (2011) School autonomy and accountability: Are they related to student performance? PISA in Focus 9 (October). Available online at: http://www.oecd.org/pisa/48910490.pdf (accessed 8 November 2012).

OECD (2012a) Does money buy strong performance in PISA? PISA in Focus 13 (February). Available online at: http://www.oecd.org/pisa/49685503.pdf (accessed 20 April 2012).

OECD (2012b) Equity and quality in education: Supporting disadvantaged students and schools (Paris, OECD).

OECD (2012c) PISA 2009 technical report (Paris, OECD).

Raudenbush, S.W. (1988) Educational applications of hierarchical linear model, $A$ review, fournal of Educational Statistics, 13(2), 85-116.

Raudenbush, S.W. \& Bryk, A.S. (2002) Hierarchical linear models: Applications and data analysis methods (CA, Sage, Newbury Park).

Raudenbush, S.W., Bryk, A.S. \& Congdon, R. (2004) HLM 6 for Windows [Computer software] (IL, Scientific Software International, Skokie).

Seymour, P., Aro, M. \& Erskine, J. (2003) Foundation literacy acquisition in European orthographies, British fournal of Psychology, 94(2), 143-174.

Snijders, T. \& Bosker, R. (1999) Multilevel analysis. An introduction to basic and advanced multilevel modelling (London, Sage).

Snow, C.E., Burns, S.M. \& Griffin, P. (Eds) (1998) Preventing reading difficulties in young children (Washington (DC, National Academy Press)).

Spörer, N., Brunstein, J. \& Kieschke, U. (2009) Improving students' reading comprehension skills: Effects of strategy instruction and reciprocal teaching, Learning and Instruction, 19(3), 272286.

Takala, M. (2006) The effects of reciprocal teaching on reading comprehension in mainstream and special (SLI) education, Scandinavian fournal of Educational Research, 50(5), 559-576.

Taylor, B.M., Pearson, P.D., Clark, K. \& Walpole, S. (2000) Effective schools and accomplished teachers: Lessons about primary grade reading instruction in low income schools, The Elementary School Fournal, 101(2), 121-165.

Van de Werfhorst, H.G. \& Mijs, J.J.B. (2010) Achievement inequality and the institutional structure of educational systems: A comparative perspective, Annual Review of Sociology, 36, 407428.

Woessmann, L. et al. (2007) School accountability, autonomy, choice, and the level of student achievement: international evidence from PISA 2003. OECD Education Working Papers, No. 13 (Paris, OECD Publishing). 


\section{Author Query Form}

\section{Journal: $\quad$ BERJ}

\section{Article: $\quad 3125$}

Dear Author,

During the copy-editing of your paper, the following queries arose. Please respond to these by marking up your proofs with the necessary changes/additions. Please write your answers on the query sheet if there is insufficient space on the page proofs. Please write clearly and follow the conventions shown on the attached corrections sheet. If returning the proof by fax do not write too close to the paper's edge. Please remember that illegible mark-ups may delay publication.

Many thanks for your assistance.

\begin{tabular}{|l|l|l|}
\hline Query reference & Query & Remarks \\
\hline 1 & $\begin{array}{l}\text { AUTHOR: Is this correct? The sentence } \\
\text { is confusing... }\end{array}$ & \\
\hline 2 & $\begin{array}{l}\text { AUTHOR: Please supply the journal } \\
\text { issue number. }\end{array}$ & \\
\hline 3 & $\begin{array}{l}\text { AUTHOR: Please supply page numbers } \\
\text { for the chapter. }\end{array}$ & \\
\hline 4 & $\begin{array}{l}\text { AUTHOR: Please supply page numbers } \\
\text { for the chapter. }\end{array}$ & \\
\hline 5 & $\begin{array}{l}\text { AUTHOR: Please supply all editor de- } \\
\text { tails. }\end{array}$ & \\
\hline 6 & $\begin{array}{l}\text { AUTHOR: Please supply page numbers } \\
\text { for the chapter. }\end{array}$ & \\
\hline 7 & $\begin{array}{l}\text { AUTHOR: Please supply all author or } \\
\text { editor details. }\end{array}$ & \\
\hline 8 & $\begin{array}{l}\text { AUTHOR: Please also supply the journal } \\
\text { issue number. }\end{array}$ & \\
\hline 9 & $\begin{array}{l}\text { AUTHOR: Please supply all author or } \\
\text { editor details. }\end{array}$ & \\
\hline
\end{tabular}


Required software to e-Annotate PDFs: Adobe Acrobat Professional or Adobe Reader (version 8.0 or above). (Note that this document uses screenshots from Adobe Reader $\mathrm{X}$ )

The latest version of Acrobat Reader can be downloaded for free at:http://get.adobe.com/reader/

Once you have Acrobat Reader open on your computer, click on the Comment tab at the right of the toolbar:

닙

This will open up a panel down the right side of the document. The majority of tools you will use for annotating your proof will be in the Annotations section, pictured opposite. We've picked out some of these tools below:

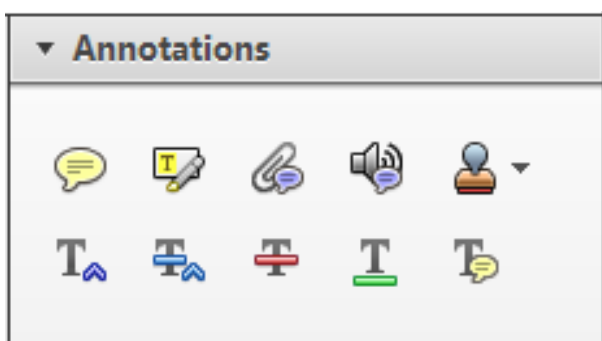

1. Replace (Ins) Tool - for replacing text.

\section{Strikes a line through text and opens up a text} box where replacement text can be entered.

\section{How to use it}

- Highlight a word or sentence.

- Click on the Replace (Ins) icon in the Annotations section.

- Type the replacement text into the blue box that appears.

Idard tramework for the analysis of $\mathrm{m}$ icy Nevertheless, it also led to exog،

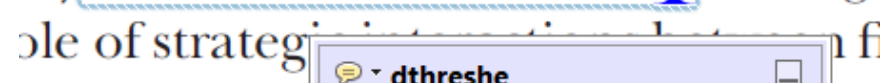
aber of comp 08/06/2011 15:58:17 $\quad$ o

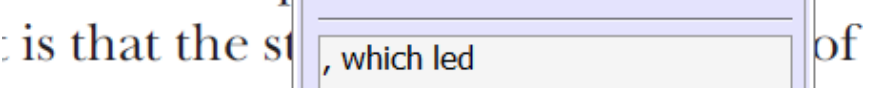
nain compo: be level, are exc nc

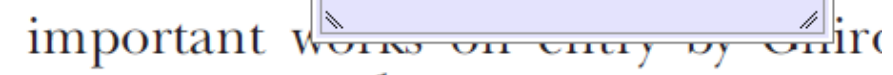
M heneforth) ${ }^{1}$ we anen the 'hlarl $\mathrm{h}$

3. Add note to text Tool - for highlighting a section to be changed to bold or italic.

Th Highlights text in yellow and opens up a text box where comments can be entered.

\section{How to use it}

- Highlight the relevant section of text.

- Click on the Add note to text icon in the Annotations section.

- Type instruction on what should be changed regarding the text into the yellow box that annears.

namic responses of mark ups ent with the VAR evidence

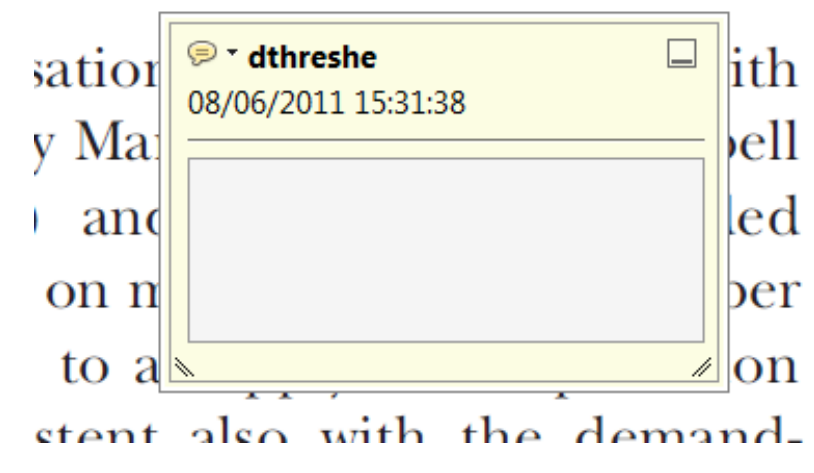

2. Strikethrough (Del) Tool - for deleting text.

Thikes a red line through text that is to be deleted.

\section{How to use it}

- Highlight a word or sentence.

- Click on the Strikethrough (Del) icon in the Annotations section.

there is no room for extra protits al c ups are zero and the number of ret) values are not determined by Blanchard and Kiyetaki (1987), rfect competition in general equilil ts of aggregate demand and supply lassical framework assuming monol eon an evorenois number of firms

\section{Add sticky note Tool - for making notes at} specific points in the text.

\section{Marks a point in the proof where a comment} needs to be highlighted.

\section{How to use it}

- Click on the Add sticky note icon in the Annotations section.

- Click at the point in the proof where the comment should be inserted.

- Type the comment into the yellow box that appears.

lallu allu suppiy silucks. Iviusl ul

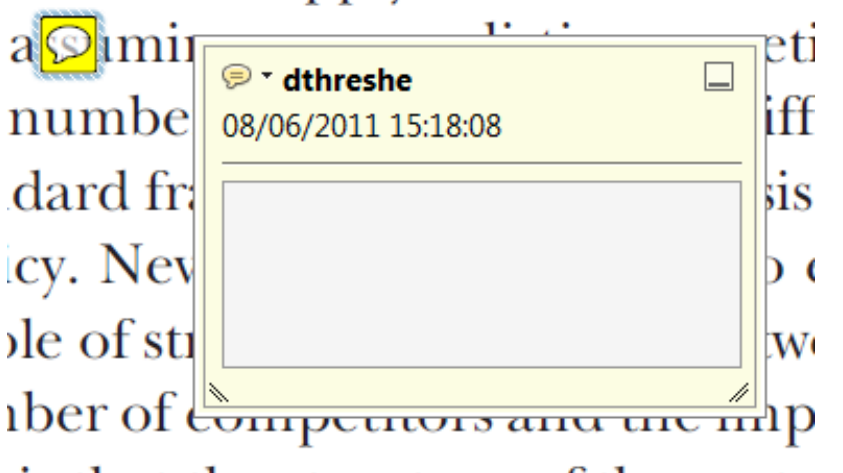

is that the structure of the secto 
5. Attach File Tool - for inserting large amounts of text or replacement figures.

Inserts an icon linking to the attached file in the appropriate pace in the text.

How to use it

- Click on the Attach File icon in the Annotations section.

- Click on the proof to where you'd like the attached file to be linked.

- Select the file to be attached from your computer or network.

- Select the colour and type of icon that will appear in the proof. Click OK.

E N D

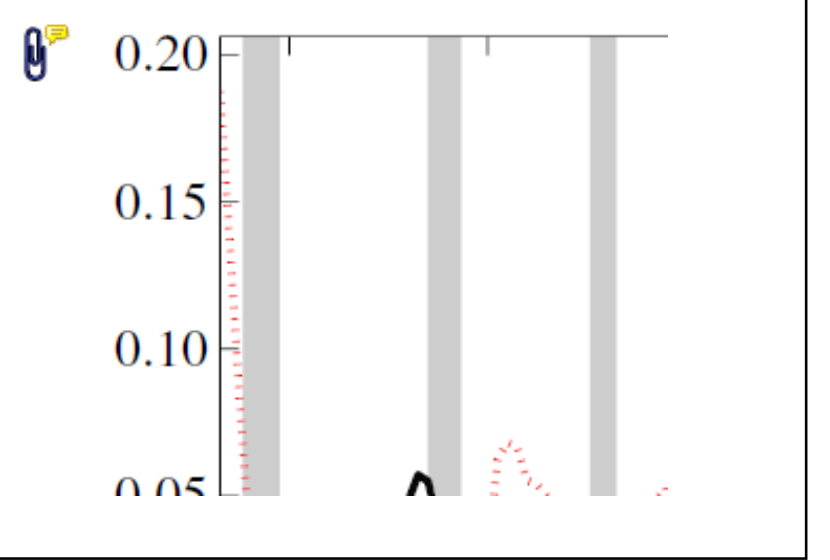

6. Add stamp Tool - for approving a proof if no corrections are required.

- Inserts a selected stamp onto an appropriate place in the proof

\section{How to use it}

- $\quad$ Click on the Add stamp icon in the Annotations section.

- Select the stamp you want to use. (The Approved stamp is usually available directly in the menu that appears).

- Click on the proof where you'd like the stamp to appear. (Where a proof is to be approved as it is, this would normally be on the first page).

of the Dusiness cycie, starting with the on perfect competition, constant ret

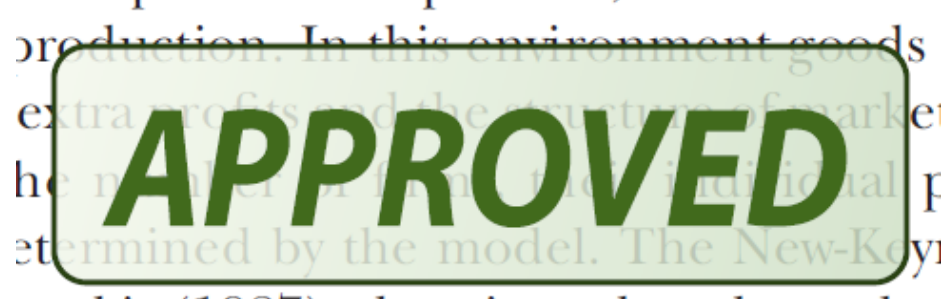

otaki (1987), has introduced produc general equilibrium models with nomin
- Drawing Markups

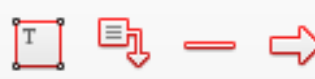

$0 \square \sqrt{6} D$

\section{How to use it}

- Click on one of the shapes in the Drawing Markups section.

- Click on the proof at the relevant point and draw the selected shape with the cursor.

- To add a comment to the drawn shape, move the cursor over the shape until an arrowhead appears.

- Double click on the shape and type any text in the red box that appears.
7. Drawing Markups Tools - for drawing shapes, lines and freeform annotations on proofs and commenting on these marks.

Allows shapes, lines and freeform annotations to be drawn on proofs and for comment to be made on these marks..

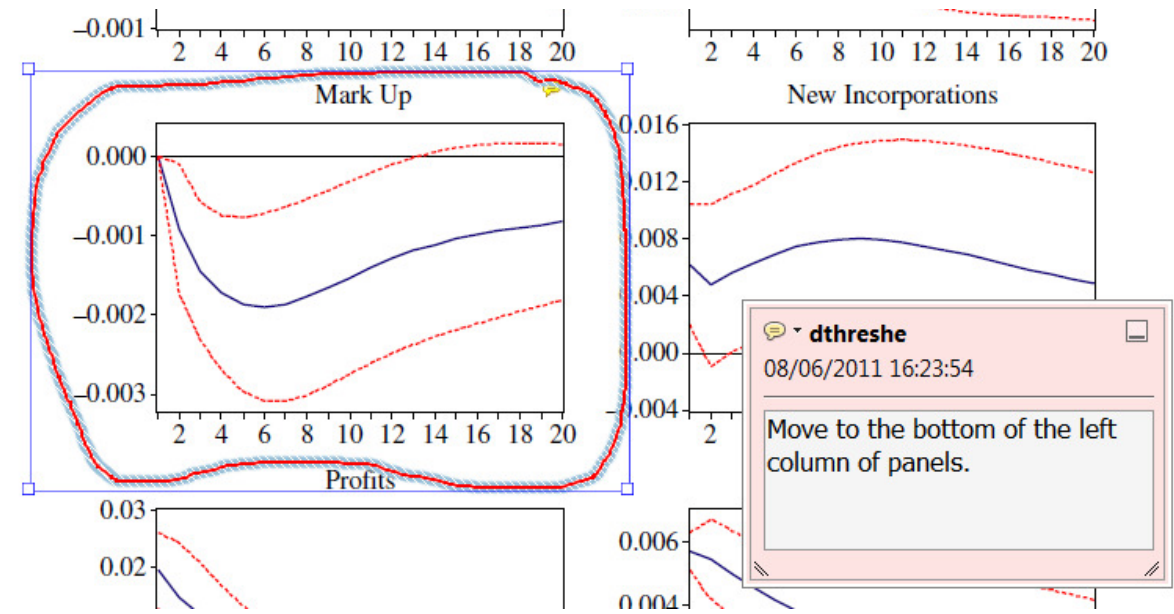

For further information on how to annotate proofs, click on the Help menu to reveal a list of further options:

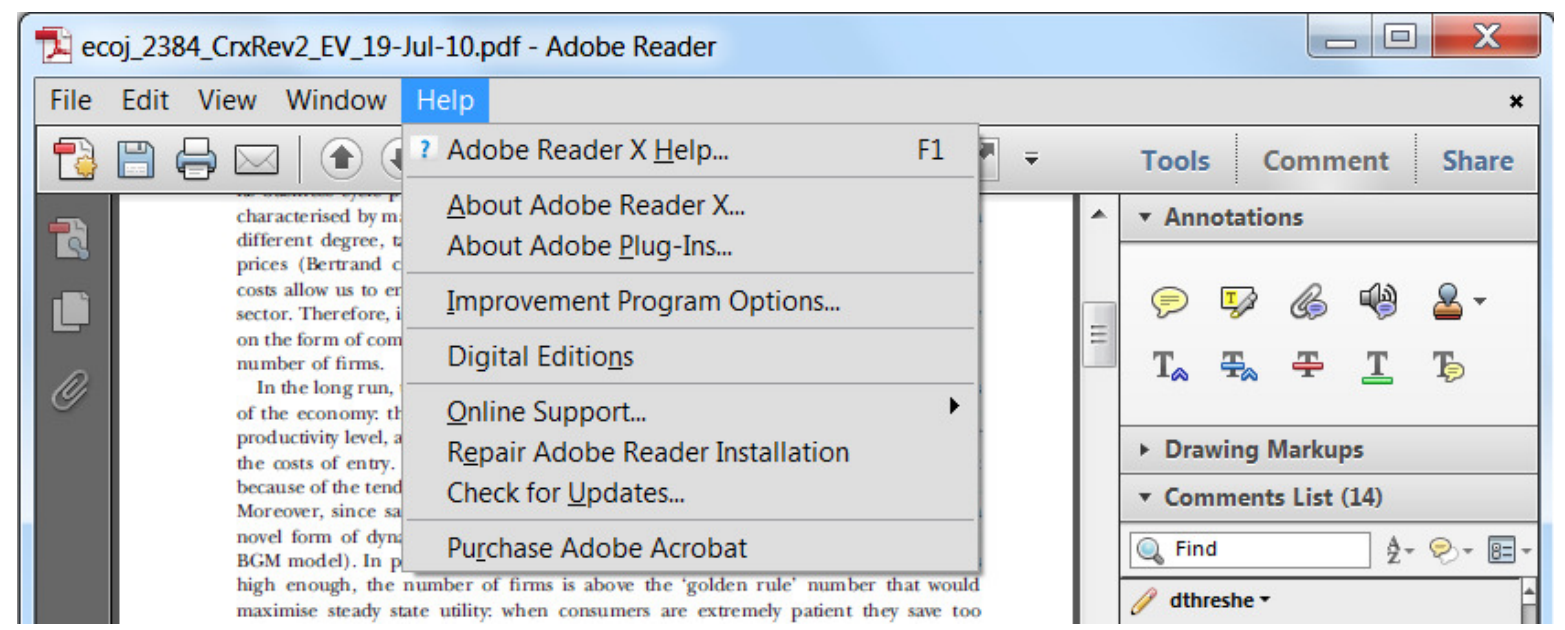

